\title{
EFEKTIVITAS PEMBELAJARAN MATEMATIKA BERBASIS WHATSAPP DITINJAU DARI HASIL BELAJAR SISWA (MASA PANDEMI COVID 19)
}

\author{
${ }^{1}$ Nurfaizah, ${ }^{2}$ Sigit Raharjo, ${ }^{3}$ Hairul Saleh \\ ${ }^{1,2,3}$ Pendidikan Matematika, Universitas Muhammadiyah Tangerang, Jalan Perintis Kemerdekaan 1/3 Cikokol \\ Kota Tangerang, 15118 \\ e-mail: nurfaizah084@gmail.com
}

\begin{abstract}
Abstrak
Pandemi covid 19 yang terjadi di Indonesia ini menyebabkan pelaksanaan pembelajaran secara daring yang dilakukan oleh seluruh sekolah di Indonesia. Berbagai macam cara dilakukan agar sekolah tetap berjalan meskipun dilakukan secara daring. Banyak aplikasi yang digunakan untuk mendukung pembelajaran siswa, salah satunya WhatsApp. WhatsApp digunakan untuk memudahkan belajar siswa melalui fitur chat maupun videocall. Oleh karena itu peneliti ingin mengetahui keefektivan belajar siswa dalam pelajaran matematika dengan menggunakan WhatsApp. Penelitian menggunakan penelitian kualitatif Dengan segala keterbatasan, peneliti melakukan pengumpulan data menggunakan kuesioner yang di bagikan pada google form. Subjek yang diambil yaitu siswa SMP dan SMA. Dilihat dari respon siswa, WhatsApp dirasa kurang efektif jika digunakan untuk pembelajaran daring matematika. Jika dilihat dari hasil belajar siswa, hasilnya pun cenderung menurun karena keterbatasan siswa dalam bertanya dan kurangnya penyampaian materi yang disampaikan oleh guru.
\end{abstract}

Kata Kunci: Matematika, Pandemi, WhatsApp

\begin{abstract}
The covid-19 pandemic has occurred in Indonesia which cause of school learning held on online throughtout Indonesia.There are many various ways to do for the school continues their learning even though by online method. Many applications used to support student learning, one of them is WhatsApp. WhatsApp used to facilitate student learning through chat and video call features. Therefore, researchers want to know the effectiveness of student learning in mathematics lessons using WhatsApp. The study will be used qualitative method. With all the limitations, the researcher collect the data by using a questionnaire which distributed with google form. The subject will be taken from junior high school and senior high school students. Refer from student responses, using WhatsApp is less effective for mathematics online learning. Based on student learning performance, the results tend to be decrease because of the limitations for students to ask and the lack of material presented by teacher.
\end{abstract}

Keywords: Mathematics, Pandemic, WhatsApp

\section{PENDAHULUAN}

Kemajuan teknologi di era disruptif ini merupakan tantangan bagi pendidik agar mampu beradaptasi dengan perubahan yang tidak pasti. Usaha transformatif dalam bidang pendidikan merupakan suatu ketentuan yang mengharuskan perubahan pola tradisional, khususnya pada sistem pembelajaran di kelas. (Kemdikbud, 2020) mengacu pada era revolusi industri 4.0 yang berdampak pada kemajuan teknologi yang semakin cepat. Kemajuan tersebut harus diaplikasikan di berbagai sektor supaya percepatan kualitas di berbagai sektor termasuk pendidikan dapat tercapai. Menurut (Wardani, Toenlioe, \& Wedi, 2018) dalam (Nur, 2020) Model pembelajaran luring di dalam kelas telah dianggap sebagai metode kuno oleh sebagian 
besar peserta didik sehingga manfaat pembelajaran daring akan memberikan spektrum inovatif yang mampu meningkatkan tingkat partisipasi dan hasil belajar peserta didik.

Menurut (Salma dkk, 2013:16) dalam (Aswindari, 2019) Kemajuan teknologi dan informasi di era globalisai berkembang sangat pesat di berbagai bidang. seperti kesehatan, sosial ekonomi, dan yang pastinya adalah bidang pendidikan. Teknologi komunikasi dan informasi yakni komponen dari pendidikan sehingga perkembangan teknologi informasi dan komunikasi memiliki peran dalam mengarahkan perkembangan pada dunia pendidikan. Majunya teknologi dalam dunia pendidikan memang sangat di butuhkan dan merupakan peran penting agar mutu pendidikan dapat meningkat.

Menurut (Yensy, 2020) Matematika merupakan cabang ilmu pengetahuan yang berperan penting dalam kehidupan di dunia dan menjadi landasan bagi ilmu-ilmu pengetahuan yang lainnya seperti fisika, kimia, dsb. Dengan mempertimbangkan pentingnya peran matematika, maka matematika merupakan salah satu mata pelajaran pokok di segala jenjang pendidikan, mulai dari Sekolah Dasar sampai dengan Perguruan Tinggi. Rintangan pembelajaran yang semakin dinamis mengharuskan adanya transformasi pola pikir guru yang semakin terlampui dengan beragam alat komunikasi, internet, dan media informasi lainnya (Sari, 2012). Berdasarkan surat edaran Mendikbud Nomor 4 Tahun 2020 (Kemdikbud, 2020) tentang pelaksanaan pembelajaran di masa pandemi coronavirus disease 19 (Covid 19) menyebabkan pembelajaran daring menjadi alternatif yang digunakan oleh guru supaya kegiatan belajar mengajar dapat tetap terlaksana (Zulkifli, 2020). Menurut Nolaputra, Wardono, \& Supriyono (2018) Pembelajaran daring merupakan terobosan yang sanggup memberikan dampak metamorfosis terhadap sistem instruksional di dalam kelas sehingga lebih memotivasi siswa (Nur, 2020).

Pembelajaran yang tetap dapat dilaksanakan selama masa darurat Covid-19 adalah pembelajaran secara online (daring). Menurut Moore, Dickson-Deane, \& Galyen (2011) dalam (Rahman, 2020) Pembelajaran online merupakan pembelajaran yang memanfaatkan jaringan internet dengan segala aksesibilitas, konektivitas, fleksibilitas, dan kemampuan untuk merangsang berbagai jenis interaksi pembelajaran. Korucu \& Alkan (2011) dalam (Setiawan et al., 2019) Mengatakan bahwa pemakaian teknologi mobilitas ini memiliki partisipasi besar dalam lembaga pendidikan, termasuk di dalamnya adalah pencapaian tujuan pembelajaran jarak jauh. Beraneka sarana juga dapat dimanfaatkan dalam mendukung pelaksanaan pembelajaran daring. Pembelajaran daring yakni proses ikatan belajar mengajar yang 
memanfaatkan jaringan internet dan tidak mengharuskan siswa bertatap muka dengan guru. Berdasarkan jenis perangkatnya, pembelajaran daring terdiri dari e-learning dan m-learning. e-learning (elektronic learning) adalah pembelajaran yang dilakukan dengan memanfaatkan alat elektronik seperti komputer atau laptop melalui jaringan internet untuk mengaksesnya, sedangkan m-learning (mobile learning) adalah pembelajaran yang diberikan dengan menggunakan gadget atau perangkat portabel lainnya. Kedua jenis pembelajaran tersebut saling berkaitan, namun e-learning digunakan jika guru mengharapkan keterampilan dan pemahaman mendalam terhadap suatu konsep dengan siswanya, sedangkan m-learning digunakan saat guru mendoktrin materi yang lebih sederhana dan memerlukan respon lebih cepat (Mansur, 2017) dalam (Nur, 2020). Pembelajaran daring dapat dilakukan dengan memanfaatkan media sosial seperti Instagram maupun Facebook (Kumar \& Nanda, 2018) dan media pesan instan yakni WhatsApp (So, 2016). Pembelajaran daring mengkoneksikan siswa dengan sumber belajarnya (database, pakar/instruktur, perpustakaan) yang secara nyata terpisah bahkan berjauhan namun tetap dapat saling berkomunikasi, berinteraksi atau berkolaborasi (secara langsung/synchronous dan secara tidak langsung/asynchronous). (Setiawan et al., 2019).

Masalah yang ditemui dalam pembelajaran matematika di Indonesia yaitu pemahaman mata pelajaran matematika yang masih sangat rendah. Media pembelajaran yang tersaji secara online pun sangat beraneka ragam dan dapat mensupport siswa agar lebih paham mata pelajaran matematika. Media pembelajaran jarak jauh yang sangat familiar dan banyak digunakan orang yakni WhatsApp (WA) yang merupakan salah satu media komunikasi yang saat ini banyak digandrungi oleh seluruh lapisan masyarakat. Penggunaan WA sudah menjadi momok penting dalam media sosial karena sudah mencakup keseluruhan kepentingan masyarakat dan kemudahan akses dalam berkomunikasi pun sudah memenuhi keperluan masing-masing.

Jumiatmoko (2016) dalam (Data et al., 2019) mengatakan bahwa WhatsApp merupakan sebuah aplikasi berbasis internet yang merangsang setiap penggunanya agar saling berbagi konten sesuai dengan layanan pendukungnya. WhatsApp juga mempunyai berbagai fitur yang dimanfaatkan untuk berkomunikasi dengan bantuan layanan internet, seperti Gallery untuk menambahkan foto, Contact untuk menyimpan kontak seseorang, Camera untuk mengambil gambar, Audio untuk menyampaikan pesan suara, Maps untuk mengirimkan berbagai koordinat lokasi, bahkan Document untuk menyisipkan berkas berupa dokumen. Semua file 
tersebut dalam sekejap dapat dikirim melalui aplikasi gratis tersebut. Fitur-fitur tersebut tentu akan memudahkan penggunanya dalam berkomunikasi melalui media online.

Aplikasi WhatsApp ini semakin lengkap juga karena adanya berbagai pilihan menu yang mendukung seperti New Group, New Broadcast, WhatsApp Web, Starred Messages dan Setting. Fitur lengkap tersebut membuat penggunanya semakin nyaman dan meningkat pesat. Hingga bulan Februari 2017, terdata pengguna aktif WhatsApp mencapai 1 miliar di setiap bulannya (Anwar N \& Riadi I, 2017) dalam (Yensy, 2020). Berbagai pilihan menu pada aplikasi WhatsApp yang salah satunya itu bernama New Group belakangan ini banyak digunakan para pelajar, mahasiswa maupun dosen sebagai media komunikasi yang terhalang oleh jarak yang diberi nama WhatsApp Group (WA Group). WA Group tersebut sudah dijadikan wadah diskusi untuk menyelesaikan berbagai masalah, baik itu pertanyaan maupun sesuatu yang harus disampaikan terhadap orang-orang yang tergabung di dalamnya. Diskusi melalui WA Group ini sangat memudahkan dan membantu penggunanya untuk berkomunikasi dalam pembelajaran jarak jauh. (Ricu Sidiq, 2019) dalam (Yensy, 2020). Namun dalam penerapannya, aplikasi ini banyak dikeluhkan oleh siswa karena minimnya interaksi antara siswa dan guru. Pendidik dianggap lebih sering memberikan tugas sehingga peserta didik merasa terbebani oleh bermacam-macam tugas tersebut (Kusuma, JW; Hamidah: 2020) dalam (Yensy, 2020).

Melihat dari fakta yang ada saat proses pembelajaran berlangsung, banyak siswa yang ketika ditugaskan untuk membuka WhatsApp namun tidak langsung membuka aplikasi tersebut dan mereka cenderung membuka aplikasi lain sehingga konsentrasi mereka tidak sepenuhnya pada pembelajaran, mereka lebih fokus pada aplikasi yang mereka buka, melihat fakta lainnya beberapa mata pelajaran yang menerapkan WhatsApp materi pembelajaran selalu dikirim sebelum pembelajaran berlangsung dengan tujuan agar siswa dapat mempelajarinya terlebih dahulu namun hanya ada beberapa siswa yang mengunduh materi dan mempelajarinya banyak diantara mereka yang kesadarannya kurang akan hal tersebut. Ketika tugas, UTS maupun UAS, harus dikirim yang telah ditentukan oleh guru dengan adanya batasan waktu pengumpulan tugas, banyak siswa yang mengalami permasalahan akibatnya beberapa mahasiswa nilai akhirnya tidak keluar.

\section{Penelitian Terdahulu}

1. Efektifitas Pembelajaran Statistika Matematika melalui Media WhatsApp Group Ditinjau dari Hasil Belajar Mahasiswa (Masa Pandemi Covid 19) 
Saat ini sistem pendidikan mendapat tantangan dengan situasi yang menuntut para pengajar untuk dapat menguasai media pembelajaran dari jarak jauh, terutama pada masa wabah pandemi Covid-19 ini. Sistem pembelajaran jarak jauh (PJJ) menjadi salah satu solusi untuk mengatasi kesulitan dalam pembelajaran tatap muka dengan menerapkan aturan social distancing mengingat permasalahan waktu, lokasi, jarak dan biaya yang menjadi kendala besar saat ini. WhatsApp Group merupakan salah satu media PJJ yang sudah banyak dikenal dan sering digunakan. Penelitian ini bertujuan untuk melihat efektif atau tidaknya pembelajaran Statistika Matematika dengan menggunakan media WA Group yang ditinjau dari hasil belajar mahasiswa. Jenis penelitian yang dipakai yaitu quasi experiment dengan mengaplikasikan one Group pretest-postest design. Sampel penelitian berupa mahasiswa semester $4 \mathrm{~b}$ yang mengambil mata kuliah Statistika Matematika sebanyak 30 orang. Data sampel diolah dengan analisis deskriptif dan uji perbedaan rata- rata menggunakan uji paired sample test dan N-Gain Score. Hasil penelitian menunjukkan Perkuliahan Mata Kuliah Statistika Matematika di Program Studi Pendidikan Matematika Jurusan PMIPA FKIP Universitas Bengkulu dengan menggunakan media WhatsApp Group cukup efektif jika dilihat dari hasil belajar mahasiswa. Setelah perkuliahan dengan menggunakan WA Group, hasil belajar mahasiswa ternyata lebih tinggi dibandingkan dengan hasil belajar mahasiswa sebelum perkuliahan dengan menggunakan WA Group. Namun, pembelajaran ini masih terdapat beberapa kelemahan, diantaranya sinyal yang susah dijangkau oleh mahasiswa yang berdomisili di daerah terpencil, chat yang banyak membuat memori Hp menjadi penuh serta cukup melelahkan karena harus bolak balik melihat chat dari awal pembelajaran. Sebaiknya bagi pihak yang tertarik melakukan penelitian serupa bisa menerapkan pembelajaran dan membandingkan dengan media lainnya mengingat masih terdapat kekurangan jika pembelajaran melalui media WA Group saja.(Yensy, 2020)

2. Peningkatan Hasil Belajar Matematika Kelas VI SDN Jumputrejo Melalui Metode Blended Lerning dengan Aplikasi WhatsApp

Hasil dari evaluasi hasil belajar ternyata cukup mengecewakan, terdapat 23 siswa dari 28 siswa atau sekitar 78,5\% siswa yang belum tuntas belajar. Untuk mengatasi permasalahan tersebut, pendidik harus mencoba untuk menggunakan metode blended learning dengan aplikasi WhatsApp Group. Tujuan dari penelitian ini yaitu mendeskripsikan penerapan metode blended learning dengan aplikasi WhatsApp. 
Penelitian ini menggunakan model penelitian tindakan dilaksanakan di SDN Jumputrejo pada semester 2 tahun pelajaran 2016/2017 pada mata pelajaran matematika materi pecahan. Berdasarkan hasil penelitian didapatkan data bahwa penggunaan blended learning dengan aplikasi WhatsApp Group dapat meningkatkan hasil belajar siswa dari 36\% pada pra siklus menjadi 57,14\% pada siklus 1 dan $85,7 \%$ pada siklus 2 . Penggunaan metode blended learning dengan aplikasi WhatsApp Group juga memungkinkan siswa untuk belajar dan berdiskusi lebih lama tanpa terikat ruang dan waktu. (Machfud, 2019)

3. Efektivitas Pembelajaran Daring Menggunakan Media Online Selama Pandemi Covid19 Pada Mata Pelajaran Matematika

Penelitian ini bertujuan untuk mengetahui gambaran efektivitas pembelajaran daring menggunakan media online selama pandemi covid-19 pada mata pelajaran matematika. Penelitian ini merupakan penelitian kuantitatif deskriptif yang fokus pada evaluasi pembelajaran menggunakan media online. Populasi penelitian yakni seluruh peserta didik SMA Negeri 1 Wajo yang diajar pada mata pelajaran matematika menggunakan metode daring. Sampel penelitian yakni peserta didik kelas XI MIPA 1 SMA Negeri 1 Wajo yang dipilih menggunakan teknik simple random sampling dengan mempertimbangkan homogenitas populasi. Instrumen pengumpulan data menggunakan kuesioner pembelajaran daring. Analisis data menggunakan statistik deskriptif. Hasil penelitian menggambarkan peserta didik menilai pembelajaran matematika menggunakan media online sangat efektif (23,3\%), sebagian besar mereka menilai efektif (46,7\%), dan menilai biasa saja (20\%). Meskipun ada juga peserta didik yang menganggap pembelajaran daring tidak efektif (10\%), dan sama sekali tidak ada (0\%) yang menilai sangat tidak efektif. Akhirnya, untuk meningkatkan kualitas pembelajaran daring matematika selama pandemi covid-19, maka pendidik harus memenuhi sepuluh saran dari responden, yakni: (1) pembelajaran dilakukan melalui video call; (2) pemberian materi pembelajaran yang ringkas; (3) meminimalisir mengirim materi dalam bentuk video berat untuk menghemat kuota; (4) pemilihan materi dalam video harus berdasarkan kriteria bahasa yang mudah dipahami; (5) tetap memberikan materi sebelum penugasan; (6) pemberian soal yang variatif dan berbeda tiap peserta didik; (7) pemberian tugas harus disertakan cara kerjanya; (8) memberikan tugas sesuai dengan jadwal pelajaran; (9) mengingatkan peserta didik jika ada tugas yang diberikan; dan (10) mengurangi tugas.(Mustakim, 2020) 


\section{METODE PENELITIAN}

Metode penelitian yang digunakan dalam penelitian ini adalah metode penelitian kualitatif. Peneliltian ini difokuskan pada satu fenomena saja yang ingin dipahami secara mendalam. Penelitian yang dilakukan ini bersifat deskriptif karena bertujuan untuk membuat deskripsi, gambaran secara sistematis tentang respon siswa terhadap bagaimana pembelajaran matematika menggunakan WhatsApp.

Adapun pendekatan kualitatif dalam penelitian ini menghasilkan data deskriptif berupa respon yang diisi oleh siswa SMP dan SMA sederajat melalui angket sebanyak 10 item pertanyaan dalam googleform yang dibagikan melalui WhatsApp. Responden memiliki kebebasan untuk memberikan jawaban atau respon sesuai dengan persepsinya.

\section{Subjek Penelitian}

penelitian ini dilaksanakan di Jl. H. Mali RT 009/01 Duri Kosambi Cengkareng Jakarta Barat. Populasi dalam penellitian ini adalah siswa-siswi SMP dan SMA sederajat diwilayah Duri Kosambi dan sekitarnya. Adapun kriteria yang dijadikan sebagai sample adalah beberapa siswa-siswi yang memiliki HP yang dapat mengakses internet.

\section{Teknik Dan Instrument Pengumpulan Data}

Teknik pengumpulan data yang digunakan dalam penelitian ini berupa angket respon siswa yang berbentuk link dari aplikasi googleform, kemudian dibagikan kepada siswa-siswi melalui WhatsApp. Sebelum digunakan, angket telah di validasi oleh validator yaitu Achmad Muslim M.si. hal ini berguna untuk mengetahui apakah angket yang digunakan layak disebarluaskan oleh siswa. Lembar validasi angket meliputi aspek isi dan Bahasa. Hasil validasi menunjukkan angket layak digunakan dengan perbaikan. Setelah diketahui permasalahannya, akan dijadikan bahan perbaikan agar angket layak digunakan.

\section{Analisis Data}

Analisa data yang digunakan pada penelitian ini yaitu:

1. Mengumpulkan Data

pengumpulan data yang digunakan dalam penelitian ini yaitu mencari informasi terkait hal-hal yang berkaitan dengan membelajaran daring melalui WhatsApp.

2. Penyajian Data 
Data hasil respon siswa disajikan dengan kalimat pendeskripsian naratif. Penyajian data tersebut dilakukan agar mudah dipahami dan dimengerti.

3. Penarikan Kesimpulan

Langkah terakhir dalam analisis data penelitian ini adalah penarikan kesimpulan. Kesimpulan dalam penelitian kualitatif dimungkinkan dapat menjawab rumusan masalah yang dirumuskan sejak awal.

\section{HASIL DAN PEMBAHASAN}

Pandemi covid 19 ini sudah berlangsung sejak awal 2020. Dengan merebaknya wabah virus corona pada pertengahan maret 2020 membuat aktifitas belajar mengajar dilakukan secara daring di rumah masing-masing. Dalam pelaksanaannya, pembelajaran daring menemui kendala dan hambatan tersendiri karena pada umumnya pembelajaran di sekolah guru bisa memantau siswa secara langsung aktivitas siswa, sedangkan saat pembelajaran daring guru hanya dapat memantau sesekali melalui gadget. Pelaksanaan pembelajaran daring juga membuat siswa merasa jenuh karena proses pembelajaran berjalan secara monoton, siswa juga kewalahan karena banyak dari mereka yang diberikan beban tugas yang terlalu banyak. Pelaksanaan pembelajaran daring yang telah dilaksanakan belakangan ini tentunya ditanggapi dengan respon yang berbeda oleh siswa siswi. Berbagai aplikasi seperti Google Classroom, Edmodo, Schoology, Zoom, Google meet dan lain-lain. Bahkan WhatsApp pun digunakan sebagai media pembelajaran daring.

WhatsApp digunakan karena pendidik dan peserta didik telah terbiasa menggunakan aplikasi ini dalam kesehariannya. WhatsApp dianggap dapat mempermudah komunikasi antara siswa dan guru saat proses pembelajaran seperti diskusi, menonton video pembelajaran, pemberian tugas serta absensi secara online. Siswa dapat bertanya kepada guru tentang materi yang sedang didiskusikan baik dengan pembahasan secara tertulis, penjelasan dengan audio dengan voice note dan penjelasan dengan video atau animasi yang dikirim oleh guru atau teman sejawat. Beberapa sekolah banyak sekali yang menggunakan WhatsApp sebagai alat komunikasi untuk pembelajaran daring.

Pelajaran matematika bukanlah pelajaran yang mudah, apalagi dipelajari saat pembelajaran daring. Matematika harus dijelaskan secara detail dan jelas apalagi saat pembelajaran daring aplikasi yang digunakan untuk belajar matematika harus efektif. untuk mengetahui efektifitas pembelajaran matematika berbasis WhatsApp, peneliti telah menyebarkan angket yang. 
Hasil angket yang telah disebarkan kepada siswa/i SMP dan SMA yakni pertanyaan pertama: Bagaimana pendapat anda tentang pembelajaran daring atau dari rumah yang selama ini di terapkan?. Adapun respon siswa terhadap pertanyaan tersebut yakni Milfa Choirunisa kelas IX mengatakan bawha ada kelebihan dan kekurangan nya sendiri menurut Milfa, mungkin akan agak sulit untuk mata pelajaran hitung menghitung. Mutiara Indah Sari kelas XII mengatakan bahwa pembelajaran daring sangat tidak efektif, lebih banyak malasnya dan konsentrasi terbagi. pemahaman materi kurang baik. Menurut Murjana kelas XII pembelajaran daring seperti ini ada sisi positif dan negatifnya. Sisi positif nya yaitu kita dapat memutuskan rantai penyebaran virus dan sisi negatif nya yaitu selama kita belajar ada materi yang kita kurang paham dan ada saja guru yang kurang respon terhadap kita maka dari itu pelajaran ada saja yg tertinggal

Syaila Syaifatunnisa kelas XII mengatakan pendapat saya mengenai pembelajaran daring selama ini adalah pembelajaran daring bisa menjadi salah satu solusi yang tepat untuk mencegah penyebaran COVID-19 meski demikian, orang-orang belum terbiasa dengan sistem seperti ini jadi banyak orang yang mengalami curtural lagi. Kusmiati kelas XII mengatakan Awal pandemi datang ke Indonesia, sekolah dan yang lainnya serba daring, yang di rasakan pertama kali sekolah daring, yang pasti senang nah senangnya karena libur atau yang lain tapi karena ini berkepanjangan, mungkin ada beberapa siswa yang merasakan bosan belajar daring/ dirumah, terutama saya sendiri bosan dalam arti, tidak bertemu teman dan tidak bisa ngobrol masalah pembelajaran secara tatap muka. Sedangkan menurut Ahmad Ziadi kelas X pembelajaran daring cukup bagus, namung dirasa kurang efektif.

Dari hasil angket pada pertanyaan pertama, dapat kita ketahui bahawa pembelajaran daring cukup bagus karena dapat memutis rantai covid 19, namun dirasa kurang efektif karena penyampaian materi kurang baik dan siswa pun merasa bosan jika belajar dirumah. Selain itu juga mereka menjari tertinggal pelajaran karena kurangnya respon guru terhadap siswa yang belum memahami materi. Hal ini justru menimbulkan rasa malas muncul di dalam diri siswa.

Hasil respon siswa dari pertanyaan kedua: Aplikasi apa yang paling anda sukai untuk pembelajaran daring?. Andika Lintang Septa Kusuma Amboro kelas XII, Diva Muzdalifah kelas XI mengatakan Zoom karena kita bertatap muka walaupun via video tapi kita bisa bertanya secara langsung tanpa perlu ribet-ribet ngetik. Tidak seperti WhatsApp ataupun google clasroom. Salsa Yulianika kelas VIII, Firna Dena Y kelas XII, mengatakan Google meet. Amanda Rifti kelas X, Sindy Adinda Permata kelas XII, dan Dika Bagas Firmansyah kelas X 
mengatakan Google Classroom. Sedangkan Heryanti kelas XII mengatakan WhatsApp dan Classroom.

Dari respon siswa diatas, dapat kita ketahui bahwa siswa lebih menyukai aplikasi yang dapat bertatap muka meskipun secara virtual. Karena lebih mempermudah siswa yang akan bertanya jika belum mengerti materi yang di sampaikan. WhatsApp dianggap kurang diminati dalam pembelajaran daring karena dianggap tidak efektif untuk pebelajaran daring .

Hasil respon siswa dari pertanyaan ketiga: Bagaimana pendapat anda tentang pembelajaran daring pelajaran matematika yang di sampaikan melalui WhatsApp?. Umayilah kelas X mengatakan pelajaran matematika waktu di sampaikan melalui WhatsApp, saya tidak terlalu paham karena tidak ada penjelasan dari bapak guru,tetapi hanya beberapa soal yang kadang bisa saya pahaminya sendiri. Milfa choirunnisa kelas XI mengatakan Jika hanya di sampaikan melalui PPT ataupun materi biasa agak busah untuk dipahami, mungkin jika bersamaan dengan cara pengerjaan soal melalui video akan lebih mudah untuk ditangkap.

Syaila Syaifatunnisa kelas XII pembelajaran daring khususnya mata pelajaran matematika yang disampaikan melalui WhatsApp sangat kurang efektif untuk dapat dimengerti dan dipahami. Amanda Rifti kelas X mengatakan Kurang efektif, karena guru tidak bisa menjelaskan dengan detail. Sedangkan Nurjana kelas X mengakatan saya kurang paham dengan materi yang disampaikan melalui WhatsApp tidak seperti ketika pembelajaran langsung.

Dari hasil respon siswa terhadap pertanyaan ketiga dapat kita ketahui bahwa pembelajaran matematika melalui WhatsApp dianggap kurang efektif karena beberapa guru hanya mengampaikan materi saja, tidak menjelaskan secara detail dan tidak mengirimkan materi dalam bentuk video pembelajaran. Hal itu membuat siswa merasa kurang mengerti jika diajarkan melalui WhatsApp

Hasil respon siswa dari pertanyaan keempat: Apakah belajar matematika secara daring menggunakan WhatsApp menyenangkan?. Mutiara Indah Sari kelas XII Kurang begitu menyenangkan mengingat fitur WhatsApp tidak banyak dan tidak ada dukungan untuk pembelajaran. Umayilah kelas X menyenangkan, namun sangat membingungkan jika tidak ada pembahasan dari bapak guru. Siti Umrah kelas IX mengatakan tidak terlalu menyenangkan karena tidak di jelaskan materinya jika melalui WhatsApp. Amanda Rifti kelas X mengatakan Tidak, karena materinya kurang dijelaskan sehingga lebih suli untuk dipahami.

Dari hasil respon siswa terhadap pertanyaan keempat yaitu pembelajaran matematika menggunakan WhatsApp kurang menyenangkan karena materi yang dijelaskan kurang begitu 
jelas dan dirasa sulit dipahami dan fitur yang ada di WhatsApp kurang mendukung pembelajaran.

Hasil respon siswa dari pertanyaan kelima: Manakah yang lebih menyenangkan belajar matematika secara daring atau pembelajaran disekolah? Refina Choirunajwa kelas IX mengatakan pembelajaran disekolah. Syaila Syaifatunnisa kelas XII belajar matematika lebih menyenangkan ketika pembelajaran di sekolah. Mutiara Indah Sari kelas XII mengatakan Disekolah karena lebih jelas bisa tanya langsung secara daring juga tidak buruk juga hanya kurang jelas saja. Dela Monica kelas XII juga mengatakan tentu saja disekolah, karena siswa akan lebih memahami jika dijelaskan secara langsung.

Dari hasil respon siswa terhadap pertanyaan kelima dapat dikatakan bahwa lebih menyenangkan belajar matematika secara langsung disekolah karena guru lebih jelas menyampaikan materinya dan siswa pun lebih leluasa jika ingin bertanya materi yang belum dimengerti.

Hasil respon siswa dari pertanyaan keenam: Apakah menurut anda pembelajaran matematika menggunakan WhatsApp cocok di terapkan pada saat pembelajaran daring? Jika iya mengapa? Jika tidak, apa aplikasi yang menurut anda cocok untuk pembelajaran matematika?. Milfa Choirunnisa kelas XI mengatakan pembelajaran matematika melalui WhatsApp salah satu cara pembelajaran yang bagus menurut saya, namun itu pun juga memiliki kekurangan nya, kalau aplikasi apa yg cocok mungkin bisa dilakukan melalui Gmeet. Mutiara Indah Sari kelas XII Mengatakan menurut saya boleh saja menggunakan WhatsApp, tetapi mengingat matematika harus dijelaskan secara jelas dan mungkin butuh waktu yang agak lama sepertinya pengajar harus membuat video dan dishare ke youtube lalu link ya dikirim ke grup belajar. Shindy Adinda Permata kelas XII mengatakan Zoom, belajar sambil dijelaskan dengan video yang diberikan oleh guru.

Diva Muzdalifah kelas IX mengatakan menurut saya pembelajaran menggunakan WhatsApp untuk materi matematika tidak cocok karna murid akan kesusahan untuk memahami materinya menurut saya aplikasi yang cocok adalah zoom karna kita bisa melihat guru kita menjelaskan materi tersebut secara rinci lebih bagus lagi menurut saya guru matematika membuat video tentang materi matematika dan di kirim ke anak muridnya agar muridnya bisa melihat cara menyelesaikan soal soal matematika. Amanda Rifti kelas X Kalau menurut saya WhatsApp kurang cocok karena guru lebih sulit menjelaskan, dan aplikasi yang cocok untuk pembelajaran daring adalah aplikasi google meet/zoom karena lebih mudah untuk guru menjelaskan dan siswa juga lebih mudah untuk bertanya dan berkomunikasi dengan guru. 
Dari hasil respon siswa pada pertanyaan keenam dapat kita ketahui bahwa WhatsApp kurang cocok digunakan untuk pembelajaran matematika. Karena matematika membutuhkan penjelasan yang jelas dan detail. Jika dilihat dari respon siswa, Aplikasi yang cocok digunakan untuk pembelajaran matematika yaitu zoom atau google meet karena guru dapat menjelaskan melalui zoom atau google meet secara virtual.

Hasil respon siswa terhadap pertanyaan ketujuh: Bagaimana perkembangan nilai matematika (Naik/turun) saat pembelajaran matematika menggunakan WhatsApp? . Diva Muzdalifah kelas XI mengatakan jujur nilai saya tengah semester agak anjlok yang tadinya biasa saya dirapot 95 jadi 82 tapi ketika ulang akhir semester nilai saya naik lagi jadi 92 . Umayilah kelas X mengatakan Alhamdulillah naik tetapi terkadang saya bertanya kepada teman yang mengerti cara-caranya. Ahmad Ziadi kelas X, Nurjanah kelas XII, dan Nurjana kelas XII mengatakan turun karena kurang memahami materi yang disampaikan. Mutiara Indah Sari kelas XII mengatakan bahwa nilainya biasa saja.

Dari hasil respon siswa pada pertanyaan ketujuh yaitu nilai siswa selama pembelajaran daring cenderung turun karena kurangnya pemahaman materi yang disampaikan oleh guru. Ketika pembelajaran daring siswa merasa tidak semangat mengikuti pembelajran karena membosankan.

Hasil respon siswa terhadap pertanyaan kedelapan: Apa saja kesulitan yang anda rasakan pada saat pembelajaran matematika melalui WhatsApp?. Amanda Rifti kelas X mengatakan sulitnyanya komunikasi dengan guru. Refina Choirunajwa kelas IX mengatakan kesulitannya ketika saya tidak mengerti beberapa soal, saya bingung harus gimana karna guru saya juga ngajar kelas lain, teman- teman saya juga lagi ngerjain. Ahmad Ziadi kelas X mengatakan kurang fokus pada pembelajaran. Salsa Yulianika kelas VII mengatakakan adanya keterbatasan dalam bertanya. Mutiara indah Sari kelas XII mengatakan bahwa terkadang WhatsApp sering down dan terdapat kendala pada sinyal.

Dari hasil respon siswa pada pertanyaan kedelapan dapat dikatakan bahwa kesulitan yang dirasakan oleh siswa yaitu sulitnya berkomunikasi dengan guru. Jika ada pertanyaan yang membingungkan terkadang siswa bingung ingin bertanya kepada siapa selain itu pembelajaran daring membuat siswa merasa kurang fokus dalam belajar selain itu juga sinyal kadang menghambat membelajaran daring.

Hasil respon siswa pada pertanyaan kesembilan: Apa kekurangan dan kelebihan yang siswa rasakan saat belajar matematika dirumah?. Milfa Choirunnisa kelas XI mengatakan kelebihan nya agak lumayan santai dalam mengerjakan soal, kekurangan nya ada beberapa soal 
yang sulit untuk dipahami karna mungkin seharusnya materi tersebut disampaikan secara tatap muka antara guru dan murid. Salsa Yulianika kelas VIII mengatakan jika tidak memiliki kuota, sulit untuk mencari informasi. Dika bagas Firmansyah kelas X mengatakan kekurangan nya susah karena kurang jelas \& kelebihan nya bisa di bantu orang tua / saudara. Kusmiyati kelas XII mengatakan kekurangannya mungkin di koneksi internet dan kelebihannya bisa menggunakan kalkulator untuk menghitung. Syaila Syaifatunnisa kelas XII Kekurangannya kurang memahami materi yang diberikan, kelebihannya lebih cermat, teliti, dan tenang ketika mengerjakan.

Dari hasil respon siswa pada pertanyaan kesembilan, dapat kita katankan bahwa kelebihan dari pembelajaran daring yaitu siswa dapat lebih santai, teliti, cermat dalam mengerjakan tugas. Selain itu siswa menganggap bahwa pembelajaran daring dapat dibantu oleh orang tua atau saudara. Kekurangannya yaitu siswa kurang fokus dalam belajra, materi yang disampaikan kurang jelas, dan terkadang sinyal menjadi hambatan dalam pembelajaran.

Hasil respon siswa pada pertanyaan kesepuluh: Jika pandemi ini belum berakhir dan pembelajaran daring akan terus dilaksanakan, bagaimana pendapat anda?. Menurut Umayilah kelas X Semoga wabah Corona cepat hilang supaya bisa masuk sekolah dan beraktivitas seperti biasa, pembelajaran daring dirumah sangat membosankan karena tidak bisa bertemu dengan teman-teman. Menurut Kusmiati kelas XII Musibah ini di rasakan oleh semua orang, pelosok desa sampai seluruh negeri pun kena pandemi ini, yg harus dilakukan hanya sabar, ikhlas, berdoa, dan jangan lupa 3M. Arsandhy Fitra kelas XII Jika itu solusi yang terbaik dari pemerintah untuk masyarakat agar pandemi ini cepat berakhir tidak apa apa. Siti Umrah kelas IX Mau tidak mau harus mengikuti karena demi keselamatan kita untuk menghindari pandemi ini.

Dari hasil respon siswa pada pertanyaan kesepuluh dapat dikatakan bahwa siswa hanya bisa berharap pandemi ini segera berakhir, jika harus melanjutkan pembelajaran daring, siswa hanya bisa mengikuti anjuran pemerintah karena untuk keselamatan bersama dan selalu menerapkan 3M.

Hasil respon siswa terhadap pembelajaran daring ini yaitu merasa bahwa pembelajaran daring dirasa cukup bagus karena dapat memutus rantai covid 19 tetapi dirasa kurang efektif karena banyak siswa yang tertinggal pelajaran karena kurang nya respon guru terhadap siswa yang belum memahami materi. Selain itu guru tidak menjelaskan secara detail, hanya mengirimkan video pembelajaran melalui grup WhatsApp. Siswa lebih menyukai pembelajaran tatap muka di sekolah karena guru lebih jelas dalam penyampaian materi. Pembelajaran ARITMATIKA, Vol. 2, No. 2, Desember 2021 
matematika menggunakan WhatsApp dirasa menghambat pembelajaran daring karena banyak siswa yang kurang paham dan tidak fokus dalam belajar yang membuat nilainya turun. Siswa lebih senang pembelajaran daring menggunakan zoom atau google meet karena dapat melihat penjelasan dari guru dah dapat langsung berkomunikasi dengan guru meskipun hanya virtual. Namun kendala sinyal membuat pembelajaran tidak maksimal. Hasil respon siswa terhadap pembelajaran daring ini akan menjadi bahan evaluasi guru untuk merancang kembali, lebih kreatif kembali dalam mempersiapkan pembelajaran terutama pembelajaran dalam jaringan. Hal-hal yang menjadi keluh kesah siswa dapat menjadi bahan pertimbangan para pemangku kebijakan untuk menentukan langkah kedepan agar menjadi lebih baik.

\section{SIMPULAN DAN SARAN}

Pembelajaran dalam jaringan masa pandemi virus corona yakni pembelajaran daring kurang menyenagkan karena materi yang dijelaskan kurang dimengerti, keterbatasan kuota, error aplikasi dan kurangnya bimbingan oleh guru. Pembelajaran di sekolah lebih menyenagkan di bandingkan dengan pembelajaran daring karena dapat bertemu teman, berdiskusi secara langsung, kurang penjelasan guru dan hanya dilakukan di rumah saja. Berbagai aplikasi digunakan untuk pembelajaran, salah satunya WhatsApp. Namun, jika dilihat dari respon siswa WhatsApp dirasa kurang efektif jika digunakan untuk pembelajaran daring matematika. Jika dilihat dari hasil belajar siswa, hasilnya pun cenderung menurun karena keterbatasan siswa dalam bertanya dan kurangnya penyampaian materi yang disampaikan oleh guru.

Ada beberapa kekurangan dan kelebihan yang dirasakan saat pembelajaran daring metematika menggunakan WhatsApp kekurangan tersebut diantaranya kendala sinyal yang kadang menghambat pembelajaran, jika siswa tidak memiliki kuota sulit untuk mencari informasi, siswa juga merasa kurang fokus selain itu juga kurangnya penjelasan guru yang disampaikan. Kelebihan yang dirasakan yaitu siswa bisa belajar dengan santai, cermat, dan dapat lebih dekat dengan saudara dan keluarga.

Saran yang dapat diberikan pada penelitian ini yakni pengharapan kepada guru untuk memberikan materi dengan semaksimal mungkin agar para siswa dapat belajar dengan semestinya.

\section{DAFTAR PUSTAKA}

Aswindari, R. (2019). Efektifitas Pembelajaran E-Learning Berbasis Schoology Pada Mata Efektivitas Pembelajaran Matematika Berbasis Whatapp Ditinjau dari Hasil Belajar Siswa (Masa 
Kuliah Media Pembelajaran Berbasis Tik Mahasiswa Pendidikan Akuntansi Ums. 2-3.

Diakses pada 23 januari 2021 dari http://eprints.ums.ac.id/74391/

Gede, I. P., \& Tubuh, S. (2018). PENERAPAN PENDIDIKAN MATEMATIKA ORANG TUA DAN HASIL BELAJAR MATEMATIKA SISWA KELAS IV-B SDN 3. 5, 554-565. Diakses pada 23 Januari 2021 dari http://idealmathedu.p4tkmatematika.org/articles/IME-V5.9-15Wibawa

Machfud. (2019). Peningkatan Hasil Belajar Matematika Kelas VI SDN Jumputrejo Melalui Metode Blanded Lerning dengan Aplikasi WhatsApp. 3(1), 43-49. Diakses pada 23 Januari 2021 dari https://jurnal.uns.ac.id/jdc/article/view/32176

Mustakim. (2020). EFEKTIVITAS PEMBELAJARAN DARING MENGGUNAKAN MEDIA ONLINE SELAMA PANDEMI COVID-19 PADA MATA PELAJARAN MATEMATIKA THE EFFECTIVENESS OF E-LEARNING USING ONLINE MEDIA DURING THE COVID-19 PANDEMIC IN MATHEMATICS. 2(1), 1-12. Diakses pada 20 Januari 2021 dari http://journal.uin-alauddin.ac.id/index.php/alasma/article/view/13646

Hartanto, W. (n.d.). Penggunaan E-Learning Sebagai Media Pembelajaran. 3. Diakses pada 25 Januari dari http://jurnal.unej.ac.id/index.php/JPE/article/view/3438

Nur, A. (2020). Pemanfaatan Schoology sebagai Sarana Pembelajaran Daring Pada Pembelajaran Matematika. Proseding Seminar Nasional Pascasarjana Universitas Negeri Jakarta, 3(Desember), 100-107. Diakses pada 5 februari 2021 dari http://journal.unj.ac.id/unj/index.php/semnas-ps/article/view/16856/9150

Nurjanah, S., \& Kusuma, A. P. (2018). Perbedaan Hasil Belajar Matematika Peserta Didik melalui Virtual Classroom Menggunakan Google Classroom dan WhatsApp Group pada Materi Bilangan Bulat di Kelas VII SMP Al-khairiyah 1 Pagi Jakarta Utara. 304-309.

Diakses pada 20 Januari 2021 dari http://jurnal.stkipkusumanegara.ac.id/index.php/semnara2020/article/view/617

Rahartri. (2019). “WHATSAPP ” MEDIA KOMUNIKASI EFEKTIF MASA KINI ( STUDI KASUS PADA LAYANAN JASA INFORMASI ILMIAH DI KAWASAN PUSPIPTEK ) Pusat Data dan Dokumentasi Ilmiah - Lembaga Ilmu Pengetahuan Indonesia . 21(2), 147156. Diakses pada $10 \quad$ Februari 2021 dari https://ejournal.perpusnas.go.id/vp/article/view/552

Rahman, S. R. (2020). Pembelajaran Online di Tengah Pandemi Covid-19. 02(02), 81-89. Diakses pada 30 Januari dari https://ojs.unsulbar.ac.id/index.php/ijes/article/view/659

Setiawan, A. R., Puspaningrum, M., \& Umam, K. (2019). Pembelajaran Fiqh Mu'Āmalāt Berorientasi Literasi Finansial. TARBAWY: Indonesian Journal of Islamic Education, 
6(2), 187-192. Diakses pada 8 Maret 2021 dari https://doi.org/10.17509/t.v6i2.20887

Sugiyono. (2016). METODE PENELITIAN Kuantitatif, Kualitatif, dan R\&D. Bandung:

Alfabeta

Yensy, N. A. (2020). Efektifitas Pembelajaran Statistika Matematika melalui Media WhatsApp Group Ditinjau dari Hasil Belajar Mahasiswa (Masa Pandemik Covid 19). Jurnal Pendidikan Matematika Raflesia, 05(02), 65-74. Diakses pada 25 Januari 2020 dari https://ejournal.unib.ac.id/index.php/jpmr

Yustanti, I., \& Novita, D. (2019). PEMANFAATAN E-LEARNING BAGI PARA PENDIDIK DI ERA DIGITAL 4 . O UTILIZATION OF E-LEARNING FOR EDUCATORS IN DIGITAL ERA 4 . O. 338-346. Diakses pada 27 Januari 2021 dari https://jurnal.univpgripalembang.ac.id/index.php/Prosidingpps/article/view/2543 